2019 TheoLogica

An International Journal for Philosophy of Religion and Philosophical Theology

ORIGINAL PAPER

DOI: https://doi.org/10.14428/thl.v2i3.15373

\title{
On Thomas Aquinas's Rejection of an 'Incarnation Anyway'
}

\author{
FELLIPE DO VALE \\ Southern Methodist University \\ dovalefellipe@gmail.com
}

\begin{abstract}
In the recent literature on whether there would have been an incarnation if there had been no fall, Thomas Aquinas is often cited as arguing for a negative answer on the grounds that it is more fitting. Little attention, however, has been given to what fittingness amounts to for Thomas, or what relation this has to the primarily biblical reasons he gives for denying an incarnation without the fall. In this paper, I argue that fittingness derives primarily from what kinds of conclusions can be drawn from the biblical text-fitting conclusions are those that, though short of necessary truths, nevertheless ought to be preferred over all of the possible alternatives because they best cohere with the nature of the scriptural canon. The answer to whether an incarnation would have occurred, for Thomas, is an example of one such biblical conclusion. I then place Thomas' arguments in conversation with contemporary advocates for an 'Incarnation Anyway' and show that their strategy of argumentation is actually accommodated by Thomas' position, leaving it safe from criticism.
\end{abstract}

Keywords: Aquinas, Incarnation, Supralapsarian, Scripture, Fittingness

Much recent attention has been given to the question of the contingency of the incarnation upon the fall. ${ }^{1}$ This has gone under the heading of 'Incarnation Anyway' (hereafter 'IA'), where 'incarnation' specifies the eternal Word's assuming a human nature in addition to his divine nature, and 'anyway' specifies the counterfactual conditions under which this would obtain, in this case independent from this (or any) fall into sin. A salutary and propaedeutic discussion to this, however, comes from scholastic debates in the $13^{\text {th }}$ century, in

\footnotetext{
${ }^{1}$ The text that has revived the discussion in contemporary dogmatics is (van Driel 2008). See also (van Driel 2017) and (Crisp 2016).
} 
which Thomas Aquinas occupies a uniquely suggestive place in the development of the question. ${ }^{2}$

Theologians have helpfully noted that Thomas' contribution lies in his subtle use of the concept of 'fittingness. ${ }^{3}$ Lying somewhere between necessity and unspecified possibility, Thomas' use of the concept renders his position more complicated than a straightforward denial of an IA (pace many who are interested in reifying the Thomist/Scotist distinction ${ }^{4}$ ). Instead, it is a more nuanced balancing of what God is able to do and what he has chosen to do. Little to no attention is given, however, as to why Thomas goes with fittingness, and what relevance his appeal to the teaching of Scripture has to the modality of his answer. In point of fact, I shall argue, his views about an IA reflects his opinions about how Scripture relates to theological conclusions; that is, that some theological conclusion $C$ is fitting is directly connected to the way that $C$ relates to Scripture, either by proceeding from Scripture's nature or is in accordance with Scripture's purposes in bringing about the greatest goods in the lives of Christians. I shall show in the final section of this paper that this approach complicates the logic of contemporary arguments in favor of an IA. Thus, what at first appeared as a speculative question (in the most pejorative sense) actually puts on display a method by which theologians should seek to be biblical in their work, while further chipping away at the misrepresentation of Thomas as the "beginning of a trajectory that had reached a dead-end in the dry and defensive anti-modern theology of neo-scholasticism and the church politics that supported it" (Healy 2005, 2).

\footnotetext{
${ }^{2}$ In this paper I will bracket the relevance of the broader historical development of the question, as my hopes are to draw out the particular benefits of Thomas' approach for contemporary theology. The $13^{\text {th }}$ century appears to have inherited its conceptual material from the felix culpa tradition dating back to the fourth century. It was Rupert of Deutz who first brought it to explicit theological consideration, and Robert Grosseteste and Alexander of Hales are significant in making the counterfactual question of whether God would have been incarnate even if humanity had not sinned common coin amongst scholastics. Thomas seems to have inherited the modal category of 'fittingness' from his teacher, Albertus Magnus, whose Commentarii in Tertium Librum Sententiarum begins with inquiring "an conveniebat Deum incarnari?" (d. 1, q. 1, a. 1). For useful accounts of the development of the question in Medieval theology, see (Westcott 1892), (Adams 2006) and (Hunter 2015).

${ }^{3}$ (Narcisse 1997) stands unsurpassed as the most thorough investigation of Thomas on fittingness. Narcisse is frequently cited as defining 'fittingness' as "a realized possibility" that carries with it implications for necessity (109) - but that to me just sounds like an actuality.

${ }_{4}^{4}$ See (Hunter 2015) for this debate, especially 174.
} 


\section{Thomas on the Contingency of the Incarnation Upon the Fall}

In this section I shall exposit Thomas' view on whether God would have become incarnate if humanity had not sinned, which I take to be one way to arrive at an answer to the question of an IA. ${ }^{5}$ It has been noted that Thomas' views on the matter remain consistent throughout his career, though there is some evidence of development. He treats it in three places-Scriptum super Sententiis (Script. Sent.) III, d. 1, q. 1, a. 3, Super Primam Epistolam ad Timotheum (ad Tim.) (1:15), lecture 4 and Summa Theologiae (ST) III, q. 1, a. 3-all of which answer the counterfactual question negatively. This led many $20^{\text {th }}$ century theologians to draw a line in theology on the matter of an IA - Thomists answer negatively, Scotists positively. ${ }^{6}$ Thus Ilia Delio: Thomas Aquinas "maintains a strict correlation between the Incarnation, sin, and redemption" (2003, 23. Emphasis added.) Recent theologians have attempted to correct such strong claims of correspondence between human sin and the incarnation in Thomas' thought, observing that if there were such a "strict correlation," then Thomas' affirmation would be incompatible with his other statements about an IA.

For instance, in his most mature treatment of the question, Thomas affirms both that "with sin not existing, the incarnation would not have been" and that "even with sin not existing, it would have been possible for God to have become incarnate." (ST III, q. 1, a. 3). ${ }^{7}$ On the one hand, he seems to say that if there had not been a fall, there could not have been an incarnation; on the other hand, he also seems to say that if there had not been a fall, there could have been an incarnation. But if the first claim is taken as a 'strict correlation,' then it is incompatible with the second claim, if for no other reason than the mere logical truth that "if not $p$ then it is not possible that $q$ " is incompatible with "if not $p$ then possibly q." Additionally, such a reading ignores the most prevalent modal concept in Thomas' Christology, namely 'fittingness': "Fittingness largely defines Aquinas' Christology and his use

\footnotetext{
${ }^{5}$ Hunter $(2015,31)$ defines three ways in which medieval theologians arrived at a conclusion about IA: a hypothetical or counterfactual question, incipient in Rupert of Deutz and found in Thomas ("Whether, if humanity had not sinned, God would have become incarnate?"); a general question about the ratio incarnationis ("Whether and how can we determine divine reasons for divine operations ad extra?"); and a specific question ("Is the redemption from sin the primary reason for the incarnation?"). He also notes that it was with Bonaventure that the question shifted from its counterfactual form to a positive question about the reason for the incarnation. Hunter helpfully shows how any of these approaches entail some kind of conclusion about IA.

${ }^{6}$ See (Bauerschmidt 2005, 459) for substantiation of this development in $20^{\text {th }}$ century Catholic theology, particularly from theological textbooks.

${ }^{7}$ All translations of Thomas Aquinas throughout this article are my own.
} 
of other modal categories" (Barnes 2012, 670). As such, most interpreters have now come to see that drawing a sharp line between Scotists and Thomists ignores the nuances of both views. As Bauerschmidt says, this approach amounts to a "serious distortion" $(2005,467)$.

So what is fittingness, and what relation does it have to Thomas' considerations about an IA? Interpreters like Bauerschmidt, Barnes and Hunter have rightly noted that one of the key roles it plays in Thomas' theology is to arrive at conclusions whose modality is somewhere between necessity and unspecified possibility. This much is evident to anyone who traces out Thomas' views on the matter. Thomas' first approach to the issue appears in his commentary on Peter Lombard's Sentences, wherein he asserts that "in the canon of Scripture and in the words of the saints this is the only cause assigned to the incarnation, namely the redemption of humanity from the servitude of sin". But this affirmation can only be said with probability: "therefore, they say this with probability, that if humanity had not sinned, the Son of God would not have become human". The emphasis on probability is meant to take into account others who say that "since through the incarnation of the Son of God not only liberation from sin might be accomplished, but also the exaltation of human nature and the consummation of the whole universe, even if sin had not existed, because of these causes there would have been an incarnation." This position, too, says Thomas, "is able to be upheld with probability" (Script. Sent. III, d. 1, q. 1, a. 3). Thus, when arriving at a theological conclusion to this question, the best to which one can aspire is a likely or probable answer. Citing the passage above, Bauerschmidt summarizes: "Thomas is clear that there is nothing external or internal that necessitates the Incarnation in the strict sense of logical necessity. Nothing in the divine nature, or in the nature of creation, compels God to enter into personal union with creatures. As an uncompelled act of divine love toward humanity and all creation, the Incarnation cannot be deduced a priori, but can only be revealed to us" $(2005,466-7)$. Thus, already as early as the Scriptum Super Sententiis, Thomas brings together the concepts of canonical consideration, modality and probability, thereby avoiding the incompatibility brought by an emphasis on strict correlation.

Turning to Thomas' commentary on 1 Timothy $1: 15,{ }^{8}$ we see similar themes. Thomas is persuaded that the ad quid of the incarnation is found in this text, namely "to save sinners," and he immediately adduces corroboration from John 3:17 and 12:47. It is in this context that Thomas returns to the familiar

8 "Fidelis sermo, et omni acceptione dignus: quod Christus Iesus venit in hunc mundum peccatores salvos facere, quorum primus ego sum," in the Vulgate. 
counterfactual question from the Sentences commentary: "But if no one had become a sinner, would the incarnation not have occurred?" (Ad Tim., 4). Thomas thinks that the evidence weighs toward the negative, given both the Scriptural teaching already mentioned and the words of the Fathers. The subsequent sentence, however, gives indication that the modal caution he displayed in the Scriptum super Sententiis is not abandoned:

But this question is not of great weight, since God has ordained that which will come about according to the things that actually were to exist. And we are ignorant of what he would have ordained if he had not foreseen sin; nevertheless, the Authorities seem to state expressly that there would not have been an Incarnation if humanity had not sinned. I am more partially inclined to this (Ad Tim., 4).

Thomas notes that God only ordains or orders events that are to obtain in the actual world - it is not possible that God will a world where Liverpool FC win the Premier League in 2019 and the world turn out to be one in which they do not win that year, for God's will is not thwarted. ${ }^{9}$ Rather, God has knowledge of these counterfactual circumstances and the conditionals that populate them, even if he does not will them (i.e., 'if Liverpool FC won the Premier League in 2019, then many Scousers would have rejoiced'). ${ }^{10}$ But do we have access to God's knowledge of counterfactual states and conditionals? No, says Thomas, "we are ignorant of what he would have ordained if he had not foreseen sin"; we only know what he has revealed in Scripture, and Scripture only contains actual events. Crisp puts it well: "The biblical material that speaks of Christ's work in the world is concerned only to explain why Christ actually came into the world" $(2016,230)$. Of course, Scripture can reveal bits and pieces of God's counterfactual knowledge to us, but this is where Thomas' weighing of the biblical material is important-we just don't seem to have this kind of information revealed to us. It is not impossible; it just did not happen. God's will is only known through revelation, and God only wills those things that become actual; therefore, all revelation is actual, and does not speak to counterfactual instances of ways God could have willed. So, concludes Thomas, when we weigh what has been revealed, we ought to lean toward denying an IA.

\footnotetext{
${ }^{9}$ Cf. ST I, q. 19, a. 6. Of course, God is able to will differently; actual events simply show that he did not.

${ }^{10}$ This will have weighty implications for fittingness, as I shall argue, but suffice it to say here that the fittingness of a given view will turn on how strictly it adheres to the actual events of revelation.
} 
So, we see something far more circumspect than a straightforward denial of an IA in the commentary on 1 Timothy. Rather, Thomas is carefully weighing the biblical material and pairing it with modal concerns. He does not want to restrict God's free action by claiming too much for human knowledge and wants to remain firmly within the auspices of Scripture. So once again, biblical and modal concerns come together with a respect for God's freedom, with the result that an answer to the counterfactual question of whether God would have become incarnate had there been no sin is something far less than certain or necessary - we "incline toward" it.

Finally, we come to Thomas' mature treatment of the matter in the Summa Theologiae. The ST is helpful for discerning Thomas' views on this topic, for it brings together the concepts already in play in his earlier work, like fittingness, ${ }^{11}$ God's will and the importance of staying within the bounds of revelation. This much is clear from the outset, for he begins his discussion with a consideration "concerning the fittingness of the incarnation itself" (ST III, a. 1, prologue). Between articles one and two, Thomas gives us a well-rounded definition of what makes something fitting. First, "to each thing, something is fitting which belongs to it by reason of its own nature" (ST III, q. 1, a. 1). A commonplace example of this, postulates Thomas, is that reason is fitting for a human being, since rationality follows from the nature of a human being. But the nature of God is goodness, and the essence of goodness is communication to others. Transitively, then, it is fitting for God to communicate himself to creatures, and this is done maximally by the incarnation. Thus, something is fitting with respect some being just in case it proceeds from or is possessed by that being's nature, and the nature in question when it comes to the fittingness of the incarnation is the divine nature. ${ }^{12}$

In article two, Thomas considers another question, namely whether it was necessary for salvation that the incarnation should occur. There are two ways "something is said to be necessary for some end" (ST III, q. 1, a. 2). According to the first, something is necessary when "without it something is not able to come about." The incarnation was not necessary for salvation in this way - there are

11 "Convenientia" is mentioned in the second article of the same question in the Commentary on the Sentences, though Thomas does not make the connection there with the claims to probabiliter in the third article. By the time of the ST that connection is made.

12 Note that here it is not human nature - there is nothing about the condition of human nature ("conditionem suae naturae") that renders it fitting to be united to God. It is above the dignity of human nature ("supra dignitatem"). Thus, it is God's goodness that graciously brings about the union of humanity and divinity (ST III, q. 1, a. 1, ad 2). I leave to the side the implications this may have for nature/grace debates. 
"many other ways" by which God could have saved. According to the second, something is necessary when that thing is the "better" and "more fitting" means of obtaining the end. Thomas here gives the famous example of the necessity of a horse for a journey; in the first kind of the necessity, I can arrive at my destination by many other means (walking, crawling, crab-walking), but riding a horse is the best and most fitting way to arrive, and the incarnation is necessary in this second kind of necessity. But what counts toward "better" and "more fitting"? "The promotion of humanity in the good" and "the withdrawal from evil" (ST III, q. 1, a. 2). ${ }^{13}$ Thomas notes five upshots to each aspect, bolstering heavy evidence for why the incarnation is necessary in virtue of its fittingness. If something can bring together (literally, "con-venire") the greatest number of goods and avoid the greatest number of evils in accomplishing some end, then it is fitting and ipso facto the necessary way to obtain that end.

So, by definition, $x$ is fitting if (a) it proceeds from or belongs to $y$ by reason of $y^{\prime}$ s nature and/or (b) is the means to achieving some end that brings together the most goods and avoids the greatest evils. ${ }^{14}$ Thus we come to ST III, q. 1, a. 3, where Thomas answers that "it is more fitting that the work of the incarnation be said to be ordained from God for the remedy of sin, so that, sin not existing, there would not have been an incarnation." Note that we have a return to the emphasis on the ordaining of God from 1 Timothy 1:15, which is one of two texts Thomas cites in the sed contra. These matters, argues Thomas, "arise only from the will of God, [being] above the entirety of the ken of a creature," and as such "they are not able to be known by us except insofar as it has been delivered in Sacred Scripture, through which the divine will is known." Here we must recall not only his comments on 1 Tim. 1:15 but also the nature of sacred doctrine, the subject matter of the ST-those things that are of God or pertain to God. ${ }^{15}$ These things "were necessary for human salvation" even though they constitute "an end which exceeds the comprehension of reason" (ST I, q. 1, a. 1). Thus, among the things that exceed the grasp of human reason and yet constitute an aspect of sacred doctrine is the matter of an IA. Consequently, our only possible answer to the question must

\footnotetext{
${ }^{13}$ Interestingly, Thomas here elides convenientia and necessitas with utile, further illustrating how the most fitting route is the one that gets the job done the best!

${ }^{14}$ My guess is that (a) and (b) are both independently necessary and sufficient conditions for fittingness, given Thomas' examples. Rationality is fitting with respect to a human being in the first kind of way, while riding a horse to a destination is fitting in the second kind of way, while neither can be construed according to the alternative way. Rationality is not a means to any end; a horse is not part of the nature of traveling.

${ }^{15}$ Cf. ST I, q. 1, a. 3, ad 1.
} 
come from revelation, which makes known to us those things about our end that escape our reason.

But these considerations would be true of any answer to the question as to whether God would have been incarnate if humanity had not sinned. It is not as if Thomas goes with the negative answer because it is the only one that depends on revealed truth as opposed to relying on human reason. Even worse, it hard to see how a reading of ST III.1.3 which merely states, "Thomas proffers a fitting answer because he relies on divinely-willed revelation," meets either of the two conditions for fittingness specified above. This is where contemporary readers of Thomas cease to be of help. For instance, Bauerschmidt tells us that "Thomas in fact thinks that unaided reason not only cannot grasp what God is, neither can it deduce a priori what God wills to do" and that "he wishes to guard the incomprehensibility of God from those who are sure they can deduce what God's nature must entail in a given possible order of things" $(2005,465,467)$; but it is hard to see how these affirmations should lead us to prefer one answer to the IA question over another. If the only criteria we have for discerning fittingness are the preservation of God's incomprehensibility and biblical dependence, how are we to discern whether we should affirm or deny an IA if they both meet the criteria? Or again, consider Hunter, who rightly notes that "the authority of Scripture and the holy expositors of Scripture, Aquinas submits, are the only means of access we have to the motive of the incarnation" $(2015,178)$. But once we have access to this motive, how are we to know where to go? Presumably it is far from self-evident what Scripture will say concerning an IA. Contemporary readers, it seems, rightly note the modal qualifications in Thomas' view without explaining how he arrives at those qualifications from Scripture.

What is needed is an account as to how a particular answer regarding an IA can be said to be fitting or unfitting with respect to the biblical text. Perhaps it can be said that denying an IA better preserves God's freedom and transcendence by means of their greater adherence to Scripture, but that only pushes the question one step further: what constitutes greater adherence? Thomas' reason that God would not have become incarnate if there had been no fall, from the Scriptum super Sententiis to the Summa Theologiae, is that this is the most fitting conclusion with respect to the Bible. But this question requires an account as to how theological conclusions relate to Scripture more broadly, and in what way that relation can be called fitting. It is the task of the second section of this paper to give such an account. 


\section{From Scripture to Theology Through Fittingness}

How ought a theologian move from Scripture to theology? That is, how does the text of Scripture relate to a dogmatic conclusion such that the conclusion is rightly called "biblical"? As I suggested, fittingness operates as one such bridge for Thomas-a theological conclusion is biblical if it is fitting with respect to the biblical text. Eugene Rogers has thus observed that Thomas' exegesis falls under "the rubric conveniens ratio, a fitting explication or suitable reason" $(2013,104)$. He cites as evidence one of Thomas' lengthiest exegetical sections in the ST, where he inquires whether there can be "a fitting cause for the sacraments of the Old Law" (ST I-II, q. 102, a. 5, ad 1). But what makes one theological conclusion a more fitting correspondence to Scripture than another?

A distinction that has been proffered recently will go some way to elucidating this matter. It comes from David Kelsey, who distinguishes between "direct" and "indirect" biblical authorizations. The former is "a direct quotation in the proper form... In such a case scripture would authorize a conclusion, i.e., authorize it without the mediation of any other authority, in response to the challenge to the conclusion. How did you get to that conclusion from this data?" $(1999,140)$. In the case of a direct authorization, mere quotation serves as sufficient warrant for authorizing a theological conclusion. "Is God love or hatred?" someone may ask. "Whoever does not love does not know God, for God is love" - and so we conclude that God is indeed love, not hatred (1 John 4:8). The banality of such an example betrays the infrequency of such direct authorizations. Far more often, argues Kelsey, theologians seek indirect authorizations for their conclusions, where Scripture is first construed as a certain kind of pattern and a decision is then made about what makes that pattern authoritative for theological conclusions. In that case, a conclusion is authorized if it conforms to the pattern in question: "what theologians appeal to... is some type of pattern in biblical texts... Judgments about them are corrigible by attending to these particularities" (1999, 193). Thus, Scripture's text is construed as a pattern admitting of right or wrong conformity, and that pattern serves as the authority for theological conclusions.

It seems to me that if we are going to begin to understand Thomas' recourse to fittingness with regard to the IA question, we must place it among conclusions seeking indirect authorization; that is, claiming that one conclusion is more fitting than another one is a claim validated by indirect authorization. We have already seen that fittingness is a concept whose modality is weaker than necessity. So it is with theological conclusions from fittingness: "Arguments from convenientia befit the realm of contingency rather than necessity" (Rogers 2013, 104). Direct 
authorizations function in deductive ways, where the conclusions follow necessarily from their premises. Kelsey notes that their internal logic is something like this: Scripture asserts $x$; if Scripture asserts $x$, then $x$ is true; therefore, $x$ is true. ${ }^{16}$ If $x$ is the conclusion of the theologian, then she has not arrived at a contingent conclusion through an inductive argument, such as an inference to the best explanation. Rather, her conclusion will necessarily follow from her premises. But from what we've seen, this is miles from the kind of conclusion at which Thomas arrives when considering the question of an IA. He arrives at a conclusion that probably follows from the premises (probabiliter). So, it must be a conclusion that receives indirect authorization.

But indirect authorization designates a variety of ways a theologian can approach her task. So what kind of indirect authorization is Thomas' 'fittingness'? For that, we must understand Thomas' ontology of Scripture so as to understand his construal of the pattern of the text. Scripture has a final cause, an end for which it is the means that obtains the greatest amount of goods and avoids the greatest amount of evils: "Therefore, so that the salvation for humans might be provided both fittingly and certainly, it was necessary that the things concerning divinity might be taught through divine revelation" (ST I, q. 1, a. 1). Notice, however, that this just is Thomas' second definition of fittingness from ST III, q. 1, a. 2, wherein the means that achieves the greatest goods and avoids the greatest evils is the most fitting and therefore the necessary means of obtaining that end. In this case, the end is God and the means to obtaining that end is divine revelation. This brings about human salvation as a good, and avoids damnation as an evil, ensuring divine revelation as a fitting means to bring us to God!

But this does not yet get us to being able to tell which conclusions drawn from Scripture are thereby fitting with it, and for that we must discern how conclusions are fitting in the other way, designated by ST III, q. 1, a. 1. We must look for a way that a theological conclusion belongs to or follows from the teaching of Scripture by reason of that teaching's nature. Here Thomas' recognition of the use of metaphors in Scripture is important. When inquiring whether Holy Scripture should use metaphors, Thomas answers:

It is fitting for Sacred Scripture to transmit divine and spiritual truth under the similitude of material things. For God provides for all things according to what belongs to their nature. Now it is natural to humanity that it arrives at intelligible things by means of sensible things, since all of our knowledge has its beginning

\footnotetext{
${ }^{16}$ I've simplified (Kelsey 1999, 141).
} 
from sense. Hence, spiritual things are fittingly transmitted to us in Sacred Scripture under the metaphors of the body (ST I, q. 1, a. 9; cf. ad 1 and 3).

Thus, God's revelation to human beings in Scripture fittingly uses metaphors on account of its nature - as a revelation to human beings, it belongs to Scripture's nature to use metaphors. This metaphorical communication then goes on to ground the fourfold sense of Scripture, with the basis on the historical sense. ${ }^{17}$ The teaching to which our conclusions consequently conform takes into account this aspect of Scripture's narrative.

Let us then bring together the various threads under consideration so as to arrive at Thomas' view of indirect authorization by means of fittingness. Kevin Vanhoozer has recently written, "To think biblically is... indwelling Scripture as a unified narrative with rich patterns (e.g. judgment and mercy) and interwoven images (e.g. sacrificial lambs) that come into greater focus as they are seen to center on Jesus Christ" and that "the supreme criterion for knowledge, goodness, beauty, and truth is Christo-dramatic fittingness" $(2015,156 ; 2005,256) .{ }^{18}$ My hope is to show that this, or something close to it, is Thomas' view, namely, that the pattern of authority is the narrative of the canon told with reference to its metaphorical sense as it points to Christ, and that theological conclusions are biblical if fitting with this construal. Vanhoozer makes mention of a "unified narrative" - Thomas, too, operates with a construal of Scripture as a coherent canonical narrative stretching from Genesis to Revelation. Recall that as early as the Sentences commentary Thomas was concerned to show that the question concerning IA is "only able to be known by the one who was born and poured out, for he has willed it." And the way this will can be known is only "in the canon of Scripture" (Script. Sent. III., d. 1, q. 1, a. 3). Or again, in both the Super Primam Epistolam ad Timotheum and the ST, Thomas makes recourse to the entire breadth of canonical witness to discern the fittingness of the denial of IA: "nevertheless, the Authorities seem to state expressly," "since everywhere in Sacred Scripture..." (ad Tim., 4; ST III, q. 1, a.3). In this way, Thomas displays what Vanhoozer has called "canonical sense." 19

Thus far we have seen that Thomas thinks that metaphors are a fitting way for God to communicate to us in Scripture and that this is displayed throughout the

\footnotetext{
${ }^{17}$ Cf. ST I, a. 1, q. 10.

${ }^{18}$ One need not get distracted by Vanhoozer's "drama" language - as I hope to show, what he means by it is not something all that different from Thomas' attention to canonical breadth.

${ }_{19}$ For further evidence of Thomas' canonical sensibilities see ad Tim., chpt. 6, lectio 1, commenting on 1 Tim. 6:3. See also ST II-II, q. 1, a. 9 ad 1. I owe these references to (Marshall 1989, 375 n. 47), whose article is a terrific help on Thomas' views about theological method and Scripture.
} 
canon. One more element remains for a full picture of Thomas' construal of the authoritative pattern of Scripture, namely the centrality of Christ to the canon. Thus he says in response to the diversity of the objects of hope throughout the canon:

The same things were always being hoped by all. Nevertheless, since humanity had not arrived at this hope except through Christ, to the measure that they were removed from Christ according to time, consequently to that measure [they were] distant from their hopes, as the apostle has said in Heb. 11[:13], "All these have died according to faith having not received the promises, but [were] recipients of them from afar." Now the measure to which something seems more far off is the measure to which that thing seems less distinct. And therefore those who perceived the good hope were the ones close to the advent of Christ (ST II-II, a. 1, q. 7, ad 1).

Thomas thinks that within the canon specificity regarding Christian hope is diverse - the measure of specificity accorded to the hope is directly correlated to the proximity the hoper has to the coming of Christ, the consummation of all hope. So, the canonical display of Scripture is not a flat topography; rather, there is a perspicuous incline from Genesis onwards to the coming of Christ, the apogee of the canonical story.

In sum, we might state Thomas' construal of Scripture for the authorization of biblical texts as follows: the entirety of the canon is a story whose metaphorical elements point to and receive greater clarity as they approach the advent of Christ, the center of the narrative. ${ }^{20}$ The remainder of the task is to show how fittingness is the means by which a theological conclusion conforms to that pattern. Recall the two ways that something can be called fitting: $x$ is fitting if (a) it proceeds from or belongs to $y$ by reason of $y^{\prime}$ s nature and/or (b) is the means to achieving some end that brings about the most goods and avoids the greatest evils. In the first sense, the relevant $x$ is a theologian's conclusion, and the relevant $y$ is Thomas' construal of the canon as a narrative centered on Christ. Thus, a theological conclusion is fitting in the first sense just in case that conclusion proceeds from or belongs to Thomas' construal of Scripture by reason of that teaching's nature. This requires careful attention to just

\footnotetext{
${ }^{20}$ My emphasis on metaphor is not intended to denigrate Thomas' adherence to the historical sense; I do not mention the historical sense simply because any appeal to a metaphor will necessarily make recourse to the historical sense. Additionally, this summary has interesting implications for those theologians who claim Thomas has a "narrative Christology," noting how questions $27-59$ of the tertia pars uniquely and closely adhere to the moments of Christ's life. The work the canonical narrative performs in Thomas' theology is fecund but frequently overlooked.
} 
what the nature of the canon is, calling for intense and acute sensitivity to the shape and contours of the canon.

This is what Thomas thinks he is offering when he argues that God would not have become incarnate had humanity not sinned -it is the sum total of the witness of Scripture with particular emphasis on Christ. When we read Scripture canonically, we see the revealed will of God, the pinpoint of which is the incarnation, life, death, descent, resurrection, ascension and session of the GodMan. This is the center of the canon, not some other counterfactual instance of the incarnation. This is the Christ that we have been given, not some other; he is the center of the canonical story, not some other. Recall that the canon reveals the actual will of God, not his counterfactual knowledge. Thus the Christ we find is the actual Christ divinely willed to be incarnate, not a counterfactually possible one. This is brought out with further clarity in later arguments for denying an IA in the tradition:

But since all Scripture proclaims that to become our Redeemer he was clothed with flesh, it is too presumptuous to imagine another reason or another end... For he who is tickled with desire to know something more, not content with God's unchangeable ordinance, also shows that he is not even content with this very Christ, who was given to us as the price of our redemption (Calvin 1960, II.12.4-5, $467,469) \cdot{ }^{21}$

Denying an IA is more fitting because it better corresponds to the nature of the narrative of the canon and its actual center, as Thomas' canonically-sensitive recourse to "everywhere" subtly indicates.

With respect to the second sense of fittingness, denying an IA is supposed to bring about the greatest number of goods and avoid the greatest number of evils. Here we can turn to ST III, q. 1, a. 2, which, after defining the kind of necessity that follows from fittingness, specifies the kinds of results the incarnation fittingly brings together. Of the ten results of the incarnation, some are contingent upon and responsive to the fall, but some are not. For instance, Thomas' fifth end for the furtherance of good is that the incarnation brings about "the full participation in divinity, which is truly the beatitude of humanity, and the end of human life. And this was conferred to us through the humanity of Christ." This is an end that obtains quite apart from our fall into sin, thereby requiring an incarnation, since it only happens through the humanity of Christ. This is noticeably different than the

\footnotetext{
${ }^{21}$ It is remarkable to note the degree to which John Calvin's position mirrors Thomas' in its logic. In this, and many other places, Calvin clearly stands as an inheritor of Thomas' view.
} 
ends the Passion brings about, found in ST III, q. 46, a. 3, all of which are contingent upon the fall. All five ends are for "salvation," or "justifying grace," or "refraining from sin," or to "overthrow the devil." What this shows is that Thomas' fittingness approach to the IA is able to accommodate the reasons given by proponents of an IA while still denying that there would have been an incarnation without sin (more on this below). What we see here is that if denying an IA is going to merit the title "fitting" in the second way, it will have sufficient breadth to bring together all of the varieties of ends the incarnation accomplishes. The more ends a view about the incarnation brings together, the greater the fittingness, giving us ample reason to favor some theological conclusion over another as more fitting.

What I hope has been shown is that Thomas' approach to the IA question is something far more nuanced than fittingness as a mere modal concept. Rather, it is a modal concept springing forth from his persuasions about the nature of the canon and theological interpretation. Fittingness is a mechanism for adjudicating moves from Scripture to theological conclusions, a mechanism that specifies what the conditions are for theological conclusions that pass muster as biblical. In short, it is Thomas' way of authorizing his claims indirectly.

\section{Thomas Among Contemporary 'IA' Theologians}

The resurgence amongst theologians interested in an IA has seemed to follow a consistent pattern of argumentation. ${ }^{22}$ The consistent pattern goes something like this: first, identify an end accomplished by the incarnation other than salvation from sin; second, show how this end does not require the fall to remain desirable as an end; third, conclude that since this is a desirable end, God would nonetheless have brought it about through an incarnation even if there had been no fall, making it an end logically prior to the fall. ${ }^{23}$ In other words, if we can specify an

\footnotetext{
${ }^{22}$ Edwin Chr. van Driel, who is perhaps the best-known proponent of this resurgence, has even appealed to considerations of fittingness in this logic. See (van Driel 2015, 362).

${ }^{23}$ For this reason, van Driel refers to his view as "supralapsarian Christology," not to be confused with debates in Reformed theology regarding the logical ordering of the decrees of God. These two discussions may implicate one another, but van Driel is clear that "it is more helpful to keep both conversations separate, as one can be a supralapsarian with regard to one doctrine, while being an infralapsarian with regard to the other" (2017, 276 n. 7). To avoid confusion, I will not adopt van Driel's nomenclature, but will nonetheless cite him on his own terms. The reader should not think that he is referring to another debate than the one at hand throughout this paper.
} 
end to the incarnation other than salvation from sin, we have identified a reason to affirm an IA. ${ }^{24}$

In what remains, I will consider two of the most prominent arguments for an IA, both of which follow the logic illustrated above. Then I will show that they do not pose a challenge to Thomas' method; if Thomas is correct, it does not follow that if the incarnation has other ends besides salvation from sin that then there would have been an IA. Rather, it is part of the fittingness of the incarnation that it has other ends, and part of the fittingness of denying an IA is that it accomplishes as many goods as possible, including ends for which affirming an IA is intended to account. In other words, Thomas' appeal to fittingness shows that proponents of an IA have not yet established their conclusion-merely showing that other ends obtain apart from a fall is compatible (and fitting) with denying an IA, so if they are to be persuasive as arguments for an IA, they not only need to identify these ends, but must also show why a denier of IA cannot happily affirm these ends too. ${ }^{25}$ To illustrate: Edwin van Driel argues, "if the incarnation inaugurates the eschatological life, in all the glory of Easter morning, the gift of the incarnation cannot be fully explained as a divine emergency measure triggered by human $\sin ^{\prime \prime}$ (2008, 148). Thomas Aquinas, however, thinks it is possible to affirm the antecedent without concluding that our options for the consequent are either 'then affirm an IA' or 'then the incarnation is only triggered by human sin.' Rather, his fittingness approach accommodates all of the glories of Easter morning without affirming an IA.

Consider, first, van Driel's argument from 'eschatological superabundance.' He argues:

The eschaton is not the restoration of the proton. In the eschaton there is an abundance, a richness in intimacy with God and in human transformation that the proton did not know. In Christ we gain more than we lost in Adam. However, the argument goes, such gain cannot be contingent upon sin...therefore, the richness of

${ }^{24}$ Van Driel makes a further negative argument, namely that denying an IA makes the incarnation a 'Plan B,' which he makes against New Testament scholars N.T. Wright and J. Louis Martyn: "The very thing Christ does could have been accomplished by another agent - Israel; in fact, it should have been accomplished by Israel, and it would have been done if Israel had not fallen into disobedience. But this means that, in the context of salvation, Jesus is really plan B...It is Martyn's understanding of Christ's coming as an apocalyptic invasion into this world that makes him resist a praeparatio evangelica, but it is also that very notion that makes him conceive of Christ's coming as a plan B" $(2014,232,235)$.

${ }^{25}$ Of course, someone who denies an IA then incurs the additional burden of accounting for how those other goods would have been brought about had the incarnation not occurred. 
the eschaton has to be understood in supralapsarian terms: it is not contingent upon sin. And since Christ is the embodiment of the abundance of the eschatological life, neither is the incarnation contingent upon $\sin (2008,150-1)$.

The final state of all creation has been ubiquitously held to be better than the first state, rightly observes van Driel. The improvement is due to at least two changes. The first regards human transformation: whereas we were created with the ability to sin, our final state will be one where we are unable to sin, surely an improvement. The second regards divine intimacy: "human beings come to see God as they never had before: face to face," a gesture towards the supremacy of the beatific vision in much Western theology $(2008,151)$.

Van Driel further argues that these two improvements "are intimately bound up with his [Christ's] person: they are modeled after, brought about by, and directed at him... The theological question pressed by the supralapsarian therefore is this: if the superabundance of the eschaton is thus so intimately bound up with the person of Christ, can Christ be contingent upon sin? Would this not make the eschaton itself contingent upon sin?" $(2008,152) .{ }^{26}$ In other words, the things that make the eschaton so superabundant seem to depend on the incarnation: "But our citizenship is in heaven, and from it we await a Savior, the Lord Jesus Christ, who will transform our lowly body to be like his glorious body, by the power that enables him even to subject all things to himself" (Phil. 3:20-21). The promise spoken of here seems to comprise all of the eschatological promises of heaven, which appear to depend on our being transformed into the likeness of Christ's glorious body, something he would not have without an incarnation. Thus, the superabundancy of the eschaton requires that the Son assume a human nature, and since this superabundancy is something that would have obtained whether or not there would have been a fall, we can affirm an IA.

Van Driel correctly indicates that Thomas shares his views about the superabundance of the eschaton as "the telos of human history," as he holds that the ultimate happiness of the beatific vision was not yet given to Adam (2008, 153). ${ }^{27}$ So, on his view, Thomas should hold to an IA. But is that correct? Thomas, fully aware of the eschatological purposes of the incarnation, does not think so. He notes that one of the purposes of the incarnation is the strengthening of our hope. ${ }^{28}$

\footnotetext{
${ }^{26}$ The language here is unfortunately misleading. Van Driel, when using the term 'person of Christ,' does not seem to be speaking of the personal agent of the hypostatic union, namely the second Person of the Trinity, the Logos. Instead, he is referring to the incarnate Christ.

${ }^{27}$ Cf. ST I, q. 94, a. 1.

${ }^{28}$ Cf. ST III, q. 1, a. 2.
} 
The presence of such an end does not stand outside of the view that the incarnation is most likely contingent upon sin, for the incarnation's contingency upon sin does not entail that it is restricted to being a cure for sin, at least not on Thomas' account of fittingness. Recall that on the second definition of fittingness something is fitting if it accomplishes the greatest number of goods and avoids the greatest number of evils-the actual incarnation of Christ does this by accomplishing goods independent of salvation from sin. In other words, the fitting route can accommodate more goods than the ones necessary. What's more, that an incarnation contingent upon human sin can still do this bolsters our reasons for denying an IA, since it can still bring together the desiderata of other ends and purposes. So in the end, van Driel identifies an end to the incarnation with which Thomas agrees, but which finds a happy home in his fittingness account of the denial of an IA.

Secondly, consider Oliver Crisp's recent argument for an IA which he calls the "christological union account," since the end he is specifying that is not contingent upon human sin is union with Christ. He notes that "it is not possible for sinless human creatures to take the initiative and unite themselves to God independent of an act of divine condescension and accommodation such as that envisaged in the incarnation. Even sinless human beings are not capable of this feat of metaphysical bootstrapping!" (2016, 218-9). Since the chasm that separates human beings from God involves a metaphysical size-gap, God "must take the initiative and unite himself with one of these creaturely natures, assuming it, and thereby generating an interface between divinity and humanity so that human beings may have a conduit by means of which they may be united to God" $(2016,219)$. He gives an appropriately $21^{\text {st }}$-century illustration: the incarnation is like the wi-fi hub router one acquires to connect one's devices to the Internet. The router requires at least two components - the parts that make it possible for individual items (laptops, iPhones, etc.) to connect to it, and the parts that make it able to connect to the Internet. Much in the same way, the incarnation serves as our 'wireless hub': "only if the interface between humanity and God is fully divine and fully human, having the relevant component parts that belong to each of these entities, will it be possible to generate the spiritual 'hub' by means of which human beings can be united to God, in order to participate in his divine life" $(2016,220)$. Thus, one of the ends the incarnation accomplishes is to provide the means for our union with God that bridges our metaphysical size-gap; since God has willed that we be united to him whether or not the fall occurred, it follows that the incarnation would have occurred 'anyway.' 
Crisp not only claims that his view best accommodates texts like Colossians 1, Ephesians 5 and 2 Peter 1:4, but also that "a unitive view of God's end in creation can be found...in the work of St Thomas Aquinas" (2016, 232). Borrowing from Brooke Westcott ${ }^{29}$ and citing Thomas' statement in ST III, q. 1, a. 1 that the fittingness of the incarnation comes from its purposes in divine goodness communicating itself, Crisp rightly observes that this end is "independent of questions of a fall from grace" $(2016,232)$. What's more, Thomas himself shares an emphasis on union with God, a key feature of his ecclesiology and sacramental theology. ${ }^{30}$ But is such a unitive end sufficient for an IA? It seems that Crisp's argument, like van Driel's, is liable to the same misunderstanding. Fittingness acknowledges unitive ends for the incarnation and such ends actually provide warrant for denying an IA in just the same way.

Of course, Thomas' view can only accommodate van Driel's and Crisp's arguments if they share his assumption that we cannot know which counterfactual events obtain according to God's will unless God reveals them, as argued in his commentary on 1 Tim. 1:15. ${ }^{31}$ Thus, specifying alternate ends to the incarnation does not entail an IA, but rather indicates the breadth of the actual incarnation. It could not constitute an end obtaining in a counterfactual circumstance, since Thomas thinks no such things have been revealed. All things that have been revealed are revelations of the divine will, which is always actualized, and counterfactuals are by definition not actual. If we share his views about that, then Thomas has shown that contemporary arguments for an IA do not obtain their conclusion. Yet, this may be too strong an assumption to share, revealing an Achilles' heel to Thomas' view; perhaps we do think that revelation speaks to

29 See (Westcott 1892, 300), where he states that Thomas' arguments regarding the communication of goodness in ST III, a. 1, q. 1 is "evidently wholly independent of the consequences of the Fall." He, too, follows the logic outlined above.

${ }^{30}$ See ST III, q. 48, a. 1; q. 48, a. 2 ad 1; q. 48, a.6 ad 2; III, q. 49, a. 1 and ad 4; q. 49, a. 3 ad 1-3; q. 49 , a. 4 ; and q. 49 , a. 5 .

${ }^{31}$ Crisp does not share this assumption, as suggested in $(2016,230)$. It is harder to see where van Driel stands with it. He wants to distinguish himself from counterfactual questions regarding IA and deal with "the story as we have it": "I do not ask what would have happened if we had not sinned; I ask about the incarnation as it happened, about the Christ as we have him; and my point is that the incarnation as it happened gives us so much, and is so rich in terms of divine friendship and intimacy that it cannot be explained as only a divine countermeasure against sin. Granted: the biblical narrative does not carry supralapsarianism on its sleeves, and so the case has to be made in terms of inferences and arguments. But this is not different from, let us say, the notion of a divine Trinity or the doctrine of the two natures of Christ. In that sense, supralapsarian Christology is thus in good company" $(2015,367)$. Statements like these make me think that he shares Thomas' assumption (and the first part could actually come from the mouth of Thomas himself!). 
counterfactual circumstances and their conditionals. Even if that is the case, Scripture would have to speak directly to this particular counterfactual state of affairs, namely, that there would have been an incarnation had there been no sin. But neither Crisp nor van Driel think this is available to us. All the same, Thomas thinks that Scripture is the narrative of salvation that actually obtains, not one that speaks to what will not obtain in the actual world. As such, it does not speak to counterfactual worlds and their conditionals.

\section{Conclusion}

In this paper I have tried to show three things. First, while contemporary interpreters of Thomas on IA rightly observe his modal qualifications, but they fall short in noting why he holds to such modal qualifications and how they arise from his interpretation of Scripture. Second, Thomas moves from Scripture to theology by means of fittingness, and conclusions from Scripture are biblical just in case they are fitting with the canonical narrative, and these conclusions have a certain modal status due to their relation to Scripture. Lastly, if we place Thomas' considerations alongside contemporary arguments for IA, he is able to accommodate their arguments and still deny an IA. This works if we share his assumptions about Scripture and what it teaches (or does not teach) about counterfactuals. In the end, Thomas' denial of an IA is deeply biblical, and it reveals his views about just what counts as such.

\section{Bibliography}

Adams, Marilyn McCord. 2006. Christ and Horrors: The Coherence of Christology. Current Issues in Theology. Cambridge: Cambridge University Press.

Barnes, Corey L. 2012. "Necessary, Fitting, or Possible: The Shape of Scholastic Christology." Nova et Vetera, English Edition 10 (3): 657-88.

Bauerschmidt, Frederick Christian. 2005. "Incarnation, Redemption, and the Character of God." Nova et Vetera, English Edition 3 (3): 459-72.

Calvin, John. 1960. Institutes of the Christian Religion. Edited by John T. McNeill. Translated by Ford Lewis Battles. Vol. 1. Philadelphia: Westminster.

Crisp, Oliver D. 2016. "Incarnation without the Fall." Journal of Reformed Theology 10: 215-33. https://doi.org/10.1163/15697312-01003016.

Ilia Delio. 2003. "Revisiting the Franciscan Doctrine of Christ," Theological Studies, 64: 3-23. https://doi.org/10.1177/004056390306400101. 
Driel, Edwin Chr. van. 2008. Incarnation Anyway: Arguments for Supralapsarian Christology. AAR Academy Series. New York: Oxford University Press.

Driel, Edwin Chr. van. 2014. "Christ in Paul's Narrative: Salvation History, Apocalyptic Invasion, and Supralapsarian Theology." In Galatians and Christian Theology: Justification, the Gospel, and Ethics in Paul's Letter, edited by Mark W. Elliott, Scott J. Hafemann, N.T. Wright, and John Frederick, 230-38. Grand Rapids: Baker Academic.

Driel, Edwin Chr. van. 2015. "To Know Nothing Except Jesus Christ, and Him Crucified': Supralapsarian Christology and a Theology of the Cross." In The Wisdom and Foolishness of God: First Corinthians 1-2 in Theological Exploration, edited by Christophe Chalamet and Hans-Christoph Askani, 359-82. Minneapolis: Fortress Press.

Driel, Edwin Chr. van. 2017. “'Too Lowly to Reach God Without a Mediator”: John Calvin's Supralapsarian Eschatological Narrative." Modern Theology 33 (2): 27592. https://doi.org/10.1111/moth.12314.

Healy, Nicholas M. 2005. "Introduction." In Aquinas on Scripture: An Introduction to His Biblical Commentaries, edited by Thomas G. Weinandy, Daniel A. Keating, and John P. Yocum, 1-20. London: T\&T Clark.

Hunter, Justus. 2015. "The Motive of the Incarnation from Anselm of Canterbury to John Duns Scotus." PhD. Dissertation, Dallas: Southern Methodist University.

Kelsey, David H. 1999. Proving Doctrine: The Uses of Scripture in Modern Theology. Harrisburg, PA: Trinity Press.

Bruce Marshall. 1989. "Aquinas as Postliberal Theologian," The Thomist, vol. 53, no. 3: 353-402. https://doi.org/10.1353/tho.1989.0017.

Narcisse, Gilbert. 1997. Les Raisons de Dieu: Arguments de Convenance et Esthétique Théologique Selon Saint Thomas d'Aquin et Hans Urs von Balthasar. Fribourg: Éditions Universitaires.

Rogers, Jr., Eugene F. 2013. Aquinas and the Supreme Court: Race, Gender, and the Failure of Natural Law in Thomas's Biblical Commentaries. Challenges in Contemporary Theology. Oxford: Blackwell.

Vanhoozer, Kevin J. 2005. The Drama of Doctrine: A Canonical-Linguistic Approach to Christian Theology. Louisville: Westminster John Knox Press.

Vanhoozer, Kevin J.. 2015. "Scripture and Theology: On 'Proving' Doctrine Biblically." In The Routledge Companion to the Practice of Christian Theology, edited by Mike Higton and James Fodor, 141-59. London: Routledge. 
ON THOMAS AQUINAS'S REJECTION OF AN ‘INCARNATION ANYWAY’

Westcott, Brooke Foss. 1892. "The Gospel of Creation." In The Epistles of St. John: The Greek Text with Notes and Essays, Third Edition, 286-328. Cambridge and London: Macmillan.

Published Online: January 26, 2019 